
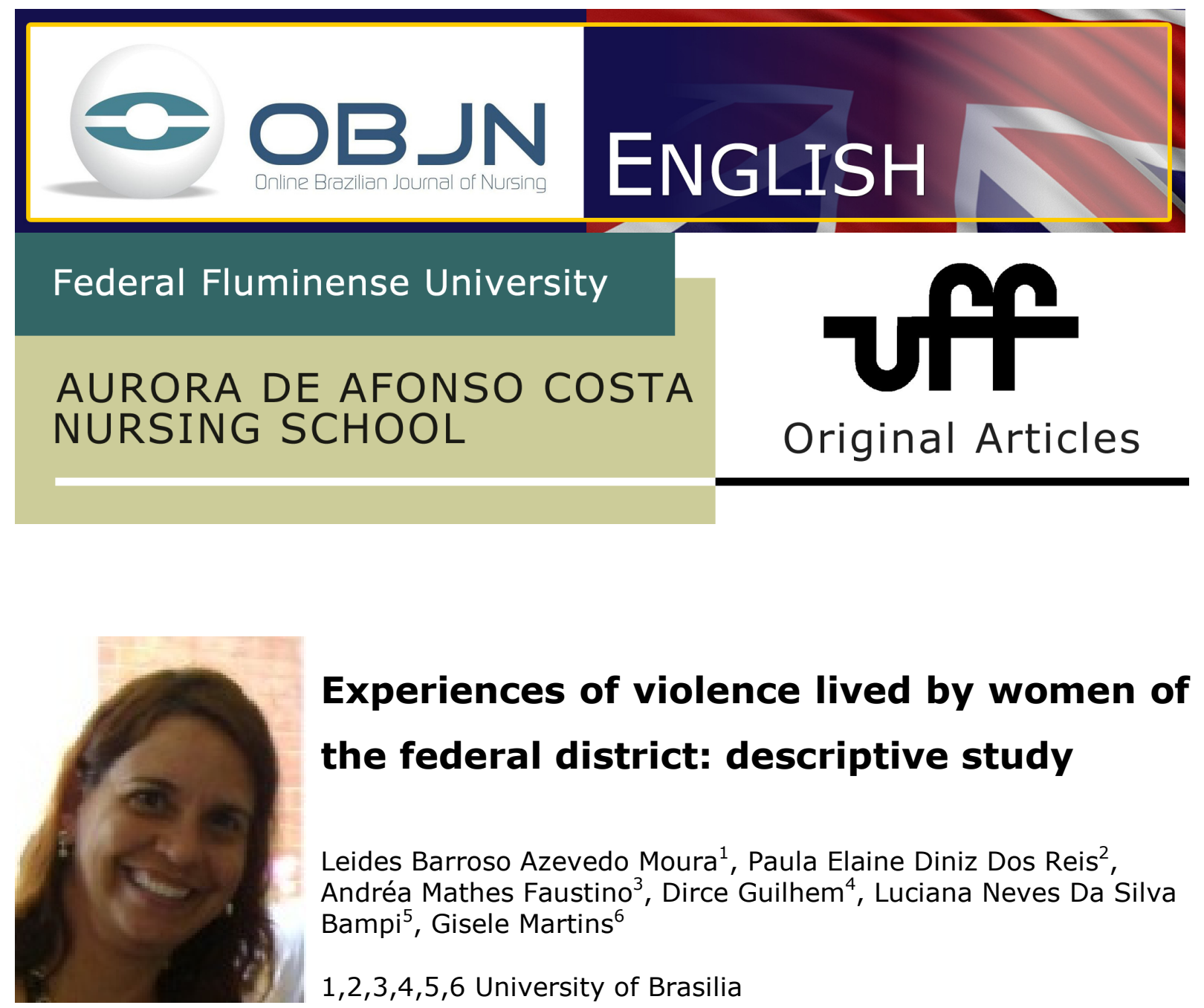

\title{
Experiences of violence lived by women of the federal district: descriptive study
}

Leides Barroso Azevedo Moura ${ }^{1}$, Paula Elaine Diniz Dos Reis ${ }^{2}$, Andréa Mathes Faustino ${ }^{3}$, Dirce Guilhem ${ }^{4}$, Luciana Neves Da Silva Bampi $^{5}$, Gisele Martins ${ }^{6}$

$1,2,3,4,5,6$ University of Brasilia

\begin{abstract}
Objective: To analyze the occurrence of the phenomenon of physical violence within intimate and affective relationships involving women aged 15 to 49 years living in an economically vulnerable area of the Federal District. Method: Cross-sectional study in a random sample and the ecological model. We used chi-square test, significance level $(5 \%)$, odds ratios (OR) adjusted and confidence interval (95\%). Results: $58.6 \%$ of women suffered some kind of physical violence throughout life of which only $5.8 \%$ sought health care. Drug use (OR 14:27, CI 1.73 - 117.37) and increased control of behavior by the partner (OR 13.39, CI 4.60-38.99) had the highest odds ratio for physical violence against women. Conclusion: The high prevalence of use of force in intimate relationships suggests the need for an investigation of abuses of power in intimate and affective relationships of women attended by nurse and practitioners of the health team. Keywords: Violence, Violence Against Women; Spouse Maltreatment, Sexual Partners, Power (Psychology).
\end{abstract}

Moura LBA ,Reis PED ,Faustino AM ,Guilhem D,Bampi LNS ,Martins G. VIVÊNCIAS DE VIOLÊNCIA EXPERIMENTADAS POR MULHERES DO DISTRITO FEDERAL: ESTÚDO DESCRITIVO. Online braz. J. nurs. (Online); 10(3) set-dez. 2011. 


\section{INTRODUCTION}

The scenarios of violence, multi-determined and polysemic, involve the whole society with all its complex dimensions - social, economic, political and cultural - requiring an approach that addresses the intersectoral and transversality which is demand by the concept of gender. Describe the mosaic of the variables involved in violent behavior using relational and dynamic category denominated "gender" is an ongoing task in studies involving the relationship between male and female. In this sense, gender is a matter of learning and "continuous work" and not an area of biological differentiation. Thus, the physical violence becomes instruments for the course of the bodies and annihilation of resistors, through the application of coercion and punitive methods ${ }^{(1)}$. The World Health Organization (WHO) defines physical abuse as "action or omission that endangers or causes damage to the physical integrity of a person"(2). It includes, but is not limited to: scratching, slapping or throwing objects with the intent of hurting the woman, pushing or shaking, hitting with fist or object, kicking, dragging or beating, biting, hair pulling, choking, burning and threaten to use or using a firearm, knife or another type of weapon against women.

Nationwide, data collected in 74 units by the Surveillance System for Violence and Accidents (SSVA) of the Ministry of Health show that physical abuse accounted for $94.1 \%$ of services for victims of violence in the sentinels of 23 capitals and Federal District in 2009. The data depict the severe physical violence, since the information of SSVA capture more easily the violence that demanded urgent and emergency care in hospitals ${ }^{(3)}$. Earlier studies had already described the high prevalence of the phenomenon $^{(4)}$.

Internationally, several studies narrate scenes and rural and urban settings ${ }^{(5-6)}$ of multiple fights for the dignity of women regarding the continuing maintenance of hierarchy and naturalization of power relations based on dominant-subordinate dyad, of 
violence suffered and practiced by women and men in family living and the intergenerational aspect of socialization mediated by experiences of violence.

In a special way, this study sought to understand the process involved in physical violence perpetrated by caregivers and male intimate partners against women, in order to analyze the physical violence within intimate and affective relationships involving women aged 15 to 49 years living in a socioeconomically vulnerable area of the Federal District.

\section{METHODS}

Cross-sectional study of descriptive analytical outlining, with a convenience sample, and the inclusion criteria: being a woman aged between 15 and 49 years, i.e., that was in reproductive age, had an intimate partner, living in the administrative region known as Varjão, located in the Federal District in 2007.

The women were randomly selected through the random selection of residences in which interviews were made, where in one of six households an interview was made. For the process of data collection was used an instrument developed by WHO (2), which includes techniques for in-depth interviews and focus groups.

With this, the research enabled the achievement of the estimation of significant associations among socio-demographic, family and community variables, using a logistic regression model of multiple possibilities. These variables were grouped according to the ecological model of violence ${ }^{(7)}$, assuming that the boundaries between individual, family, community and society are cross-fertilized by the social field.

Moura LBA ,Reis PED ,Faustino AM ,Guilhem D,Bampi LNS ,Martins G. VIVÊNCIAS DE VIOLÊNCIA EXPERIMENTADAS POR MULHERES DO DISTRITO FEDERAL: ESTUDO DESCRITIVO. Online braz. J. nurs. (Online); 10(3) set-dez. 2011. 
The dependent variable analyzed was the occurrence or not of physical violence by intimate partners at some point in life. To operationalize the data collection, we used systematic probabilistic sampling, identical to that used by the IBGE in household surveys.

Thus, it was estimated that the total number of resident families in Varjão was 1800, based on Census 2000, considering as sampling fraction $1 / 6$, or $16.7 \%$. In each household, families were identified and in each family, we listed women aged 15 to 49 years for subsequent probabilistic selection.

This methodological approach was provided to assist in understanding the phenomenon of the use of physical force in intimate-emotional relationships, of the subjectivity and the cultural construction of human actions stained by the use of violence in gender relations.

The study was approved by the Ethics Committee of the Faculty of Health at the University of Brasilia (CEP-FS/UnB) under protocol $n{ }^{\circ}$ 003/2007.

\section{RESULTS}

We interviewed 300 women, but those who met the inclusion criteria were a sample of 278, aged 15-49 years, according to the flow below, Figure 1.

Moura LBA ,Reis PED ,Faustino AM ,Guilhem D,Bampi LNS ,Martins G. VIVÊNCIAS DE VIOLÊNCIA EXPERIMENTADAS POR MULHERES DO DISTRITO FEDERAL: ESTUDO DESCRITIVO. Online braz. J. nurs. (Online); 10(3) set-dez. 2011. 
Figure 1. Sampling design according to criteria for inclusion. Varjão, DF, 2007.

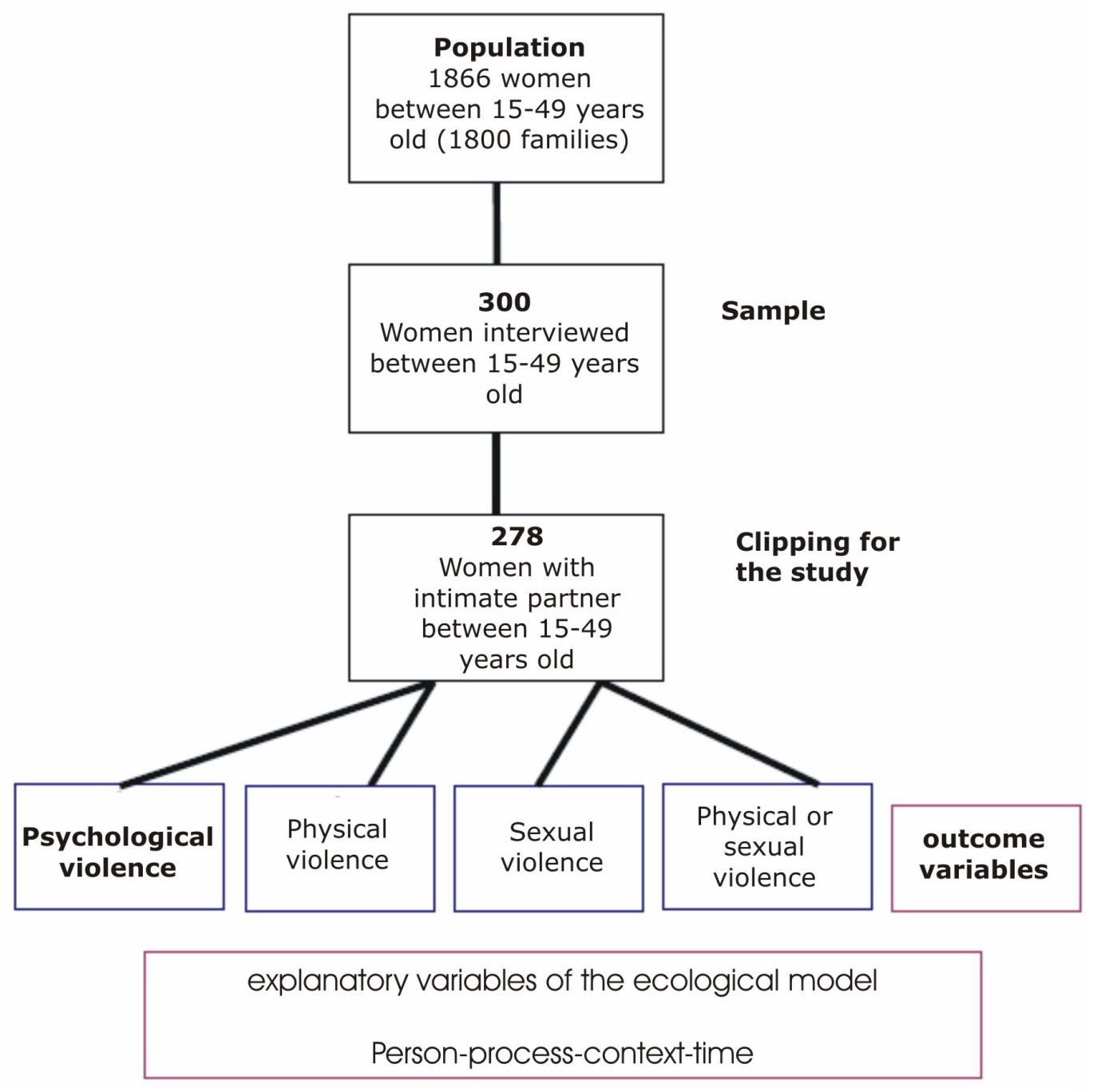

\section{*See last page}

Among the sample, $45 \%$ of respondents were aged from 25 to 34 years, mean age 30 $(S D=8.5)$ years. Regarding the degree of schooling, $74 \%$ had incomplete primary education. More than half of respondents (58\%) reported being unemployed or looking for a job at the interview. Among the serious violence $59 \%$ were perpetrated by male partners who had up to four years of schooling. The responsibility of the household was given to men for almost half of respondents (49\%), the number of people in the household ranged from 1-9 people, and the distribution was: 1 to $2(11 \%), 3-4(55 \%)$ and 5 or more (34\%).

Moura LBA, Reis PED ,Faustino AM ,Guilhem D,Bampi LNS ,Martins G. VIVÊNCIAS DE VIOLÊNCIA EXPERIMENTADAS POR MULHERES DO DISTRITO FEDERAL: ESTUDO DESCRITIVO. Online braz. J. nurs. (Online); 10(3) set-dez. 2011. 
Physical violence had a prevalence of $58.6 \%$ (95\% CI: 52.8 to 64.4 ). Among women who experienced physical violence, the severe form showed a prevalence of $72 \%$. The magnitude of the acts considered severe violence was: punching or throwing objects (30\%) kicking or beating (26\%) choking or burning $(22 \%)$ and the threat or use of weapon or firearm ( $28 \%)$. As for moderate physical violence, pushing and shaking (53\%) had the highest prevalence. But the slaps or throwing of objects $(43 \%)$ had the highest proportion of reports of repeated episodes $(45 \%)$, showing that it has occurred many times throughout life.

The study questioned if women conceived the existence of any reason for men to use physical violence in the relationship with her and it was found that $12.5 \%$ believe that a marital infidelity by the woman should be punished with the use of physical violence by the partner and $4 \%$ said that if a woman disobeys her husband or partner it would be a reason for him to hit her. In case of physical violence, $40 \%$ think that outsiders should not interfere, even if the partner is abusing the woman.

Among the socio-demographic characteristics of respondents, bivariate analysis revealed an association of variables: education level, marital status and number of marriages with the occurrence of physical violence. The lower level of education of women, the greater the frequency of reports on the occurrence of physical violence. Among those who have less than 4 years of study, the prevalence of physical violence is $73.6 \%$. However, among those with 11 or more years of study, the prevalence drops to $48.6 \%$. With regard to marital status, among women who are currently married, living or having sexual relations with a partner, $53 \%$ of them report having suffered physical violence committed by an intimate partner throughout life. For those that declare not to be in union, this prevalence rises to $83 \%$ (Table 1 ).

Moura LBA , Reis PED ,Faustino AM ,Guilhem D,Bampi LNS ,Martins G. VIVÊNCIAS DE VIOLÊNCIA EXPERIMENTADAS POR MULHERES DO DISTRITO FEDERAL: ESTUDO DESCRITIVO. Online braz. J. nurs. (Online); 10(3) set-dez. 2011. 
Table 1 - Prevalence of physical violence by an intimate partner according to sociodemographic, behavioral and contextual variables. Varjão, DF, 2007.

\begin{tabular}{|c|c|c|c|c|c|}
\hline Variables & Phís. Viol. & $\%$ & Prev. Rat. & $\chi^{2}$ & p-valor \\
\hline \multicolumn{6}{|c|}{ Socio-demographic variables of interviewed women } \\
\hline \multicolumn{6}{|l|}{ age group } \\
\hline 15 to 24 years & 39 & 54.9 & 1.00 & & \\
\hline 25 to 34 years & 73 & 58.4 & 1.06 & 0.8 & 0.659 \\
\hline 35 to 49 years & 51 & 62.2 & 1.13 & & \\
\hline \multicolumn{6}{|l|}{ Level of Education } \\
\hline More than 4 years & 53 & 73.6 & 1.51 & & \\
\hline 4 to 7 years & 58 & 57.4 & 1.18 & 10.3 & $0,016 *$ \\
\hline 8 to 10 years & 34 & 50 & 1.03 & & \\
\hline 11 or more & 18 & 48.6 & 1.00 & & \\
\hline \multicolumn{6}{|l|}{ Marital status } \\
\hline Married / living with a man / has a partner & 123 & 53.5 & 1.00 & & \\
\hline Previously married / lived with a man & 40 & 83.3 & 1.56 & 14.6 & $<0,001^{*}$ \\
\hline \multicolumn{6}{|l|}{ Number of marriages } \\
\hline Up to 1 marriage & 104 & 52.3 & 1.00 & 1.7 & $<0,001^{*}$ \\
\hline 2 or more & 59 & 74.7 & 1.43 & & \\
\hline \multicolumn{6}{|l|}{ Women's activity status } \\
\hline Working & 65 & 63.7 & 1.14 & & \\
\hline king for a job / Unemployed / Inactive & 98 & 55.7 & 1.00 & 1.7 & 0.189 \\
\hline \multicolumn{6}{|c|}{ Socio-demographic variables of the partner } \\
\hline \multicolumn{6}{|l|}{ Educational level of partner } \\
\hline Less than 4 years & 61 & 60.4 & 1.06 & & \\
\hline 4 to 7 years & 56 & 58.3 & 1.03 & & \\
\hline 8 to 10 years & 25 & 56.8 & 1.00 & 0.2 & 0.97 \\
\hline 11 or more & 21 & 56.8 & 1.00 & & \\
\hline \multicolumn{6}{|l|}{ Partner's Activity Status } \\
\hline Working & 129 & 60.6 & 1.25 & & \\
\hline king for a job / Unemployed / Inactive & 29 & 48.3 & 1.00 & 2.9 & 0.61 \\
\hline \multicolumn{6}{|l|}{ Variables of partner's behavior } \\
\hline \multicolumn{6}{|l|}{ Frequency of use of alcoholic beverages } \\
\hline Frequently & 31 & 96.9 & 2.44 & 31.2 & $<0,001 *$ \\
\hline Moderate & 83 & 61 & 1.54 & & \\
\hline Rarely & 17 & 54.8 & 1.38 & & \\
\hline Never & 31 & 39.7 & 1.00 & & \\
\hline \multicolumn{6}{|l|}{ Illicit drug use by partner } \\
\hline currently using & 26 & 86.7 & 1.78 & & \\
\hline Used in the past & 39 & 73.6 & 1.51 & 2.1 & $<0,001^{*}$ \\
\hline Never used & 92 & 48.7 & 1.00 & & \\
\hline
\end{tabular}

extramarital affairs

Moura LBA ,Reis PED ,Faustino AM ,Guilhem D,Bampi LNS ,Martins G. VIVÊNCIAS DE VIOLÊNCIA EXPERIMENTADAS POR MULHERES DO DISTRITO FEDERAL: ESTUDO DESCRITIVO. Online braz. J. nurs. (Online); 10(3) set-dez. 2011. 


$\begin{array}{llllll}\text { Yes } & 97 & 72.4 & 1.58 & 20.2<0,001^{*} \\ \text { No } & 66 & 45.8 & 1.00 & & \end{array}$

\section{Contextual variables}

Financial problems by use of alcoholic

beverages

Yes

No

$\begin{array}{lllll}54 & 87.1 & 1.54 & 17.8<0,001^{*} \\ 78 & 56.5 & 1.00\end{array}$

Family problems due to the use of alcoholic beverages

Yes

$\begin{array}{lll}72 & 81.8 & 1.53\end{array}$

$17.5<0,001^{*}$

No

$\begin{array}{lll}60 & 53.6 \quad 1.00\end{array}$

Women have family support in case of necessity

\begin{tabular}{llllll} 
Yes & 89 & 55.6 & 1.00 & 1.4 & 0.236 \\
No & 74 & 62.7 & 1.13 & & \\
\hline
\end{tabular}

The socio-demographic characteristics of the partner, level of education and activity status, were not associated with the occurrence of physical violence. However, the characteristics of partner's behavior - frequency of use of drinking and illicit drugs and extramarital affairs - proved to be associated with the occurrence of physical violence.

Of the 134 women who reported the existence of the extramarital affairs by the partner, $72 \%$ of them were victims of physical violence, and, among those who reported that the partners had no extramarital relationship, the prevalence of physical violence was of $46 \%$. That is, the prevalence of physical violence was 1.6 times higher when the partner had extramarital affairs. In the case of alcoholic beverages, in $97 \%$ of cases reported by the interviewees in which their partners used to drink frequently (every day or almost every day) there was physical violence. The use of illicit drugs was also associated with physical violence. Among women who reported that their partners currently use illicit drugs, $87 \%$ of them claim to have suffered physical violence.

The context variables - the existence of financial problems arising from the use of alcoholic beverages by the partner or family problems arising from the use of alcoholic beverages by the partner - were also associated with a higher prevalence of physical violence (Table 1).

Moura LBA, Reis PED ,Faustino AM ,Guilhem D,Bampi LNS ,Martins G. VIVÊNCIAS DE VIOLÊNCIA EXPERIMENTADAS POR MULHERES DO DISTRITO FEDERAL: ESTUDO DESCRITIVO. Online braz. J. nurs. (Online); 10(3) set-dez. 2011. 
We also analyzed the associations between violence committed by intimate partners and the explanatory variables of the ecological model according to the personal, procedural and contextual levels, using a model composed of multiple causes for analysis by logistic regression. The socio-demographic characteristics of the partner - level of education and activity status - showed no statistically significant difference in the occurrence of physical violence. However, in respect of their individual characteristics - frequency of use of drink and illegal drugs -, this difference was significant, as shown in Table 2.

Table 2. Odds ratio and confidence interval for the association between physical violence throughout life and the explanatory variables of the ecological model. Varjão, DF, 2007.

\begin{tabular}{lcc}
\hline Variables & OR & CI $(95 \%)$ \\
\hline Nível Pessoal - Entrevistada & & \\
\hline Number of marriages & 1.00 & - \\
None & 6.33 & $1.10-36.30$ \\
One & 11.04 & $1.74-69.93$ \\
Two or more & & \\
Employment & 1.00 & - \\
Looking for a job & 2.53 & $1.26-5.08$ \\
The woman has a job & & \\
\hline Personal Level - Partner & & \\
\hline Use of illicit drug by the partner & 1.00 & - \\
Do not use illicit drug & 2.07 & $0.87-4.910$ \\
Ex-drug user & 14.27 & $1.73-117.37$ \\
User & & \\
Episodes of drunkenness & 1.00 & - \\
There has never been episodes of drunkenness & 1.01 & $0.43-2.29$ \\
Monthly episodes & 2.97 & $1.13-7.78$ \\
Weekly episodes & & \\
\hline Procedural Level - Partner & & \\
\hline Number of control behaviors & 1.00 & \\
None & 3.64 & $1.57-8.42$ \\
1 to 3 & 13.39 & $4.60-38.99$ \\
4 or + & & \\
extramarital affairs & 1.00 & - \\
No & 2.19 & $1.13-4.22$ \\
Yes & & \\
Nistory of fighting with another man & 1.00 & - \\
Yes & 2.84 & $1.39-5.80$ \\
\hline Contextual Level - exosystem & & \\
\hline & & \\
\hline
\end{tabular}

Moura LBA ,Reis PED ,Faustino AM ,Guilhem D,Bampi LNS ,Martins G. VIVÊNCIAS DE VIOLÊNCIA EXPERIMENTADAS POR MULHERES DO DISTRITO FEDERAL: ESTUDO DESCRITIVO. Online braz. J. nurs. (Online); 10(3) set-dez. 2011. 


\begin{tabular}{lrc}
\hline $\begin{array}{l}\text { In the case of street fights, the neighborhood does } \\
\text { something }\end{array}$ & \\
Yes & 1.00 & - \\
No & 2.40 & $1.23-4.63$ \\
\hline Contextual Level - macrosystem & & \\
\hline Women's preoccupation with crime in the community & & \\
Not Concerned & 1.00 & - \\
Is very concerned & 4.23 & $1.17-15.29$ \\
\hline
\end{tabular}

Women who experienced more physical violence throughout their lives were those whose partners are drug users $(O R=14.27)$, with episodes of weekly drunkenness $(O R=2.97)$, using four or more control behaviors in the relationship with them $(O R=13.39)$, had extramarital relationships $(O R=2.19)$ and have a history of fights with other men $(O R=2.84)$. This multidimensional picture shows the variety of situations that were found associated with the outcome variable (Table 2).

More than half of the 163 women who narrated their stories of physical violence over the life $(51 \%)$ reported suffering injuries as a result of partner physical aggression. Among these, $46 \%$ said that injuries occurred once or twice, $14 \%$ had suffered injuries from three to five times, and $38 \%$ said that episodes of violence by the partner resulted in a high frequency of lesions in more than five occasions. However, only $5.8 \%$ sought care in hospitals and primary care services.

\section{DISCUSSION}

In a cultural perspective, a study that deals with the psychic transmission of domestic violence, reports the establishment of power relations in the family. It explains that violent content is transmitted in a intergenerational manner, which includes a space to metabolize psychic material, and transgenerational, as an unconscious psychic fact that crosses several generations $^{(8)}$. The occurrence of physical violence in intimate affective relationships endangers children, adolescents and elderly people residing in these households and results in increasing the magnitude of the number of victims involved in experiences of violence ${ }^{(2,8-10)}$. 
In this sense, to study the gender-based violence requires transcending the impact on women's health and enhance the look of the health team to human health and the family. It should be noted that the nurse occupies a privileged listening and caring position at basic health units and in hospital emergency where victims of such violence are being attended. The low demand for health services reported by the interviewees may suggest, among other factors, a difficulty of such services, as well as their professionals, to act in violence prevention and victims' care.

Most of the violence described by the women was of severe intensity and were not confined to isolated incidents, but to the recurrence of violent acts. The consequences of this violence on women's health and the health problems related to the everyday occurrence of physical violence are widely publicized in national and international academic community ${ }^{(2,8)}$.

In the investigation carried out by the Ministry of Health, it is reported the occurrence of repeated episodes of violence in $39.7 \%$ of the cases $^{(3)}$. Violence against women is today a public health problem and fighting against this problem constitutes a priority for agencies defending human rights ${ }^{(4)}$. Reducing the waste of life goes through eradicating Gender-Based Violence (GBV), requires a professional effort of nursing to recognize the episodes of violence and assist victims to obtain access to social support network.

The results of this study emphasize human interactions marked by the use of physical force in the context of intimate-affective relations and show a reality that is incompatible with the era of human rights and the advancement of contemporary civilization. There is a stereotypical masculinity in which men who engage in physical violence in intimateaffective relations also engage themselves in physical aggression with other men on the street and use control behavior based in the domination of male over female regarding their partners ${ }^{(10)}$.

Hence, we realize that the key to interpreting these data is the imbrication of the relational concept of gender and masculinity that is found in control behaviors, a form of language, a communicative process that interacts with other variables, either directly or 
indirectly, and produces scenarios of multiple violence based on hierarchical power relationships. The control behaviors are discourses of delimitation of ownership and establishment of property.

\section{CONCLUSION}

The prevalence of physical violence committed against the interviewed women reveals that the central issue addressed lies in human beings and their permanent state of vulnerability and precariousness of physical and existential integrity. The use of punitive and coercive force in the form of physical force expresses the size of the gap - the distance - to tread toward a civilizational matrix that does not violate human integrity and dignity. The high prevalence of use of force in intimate and family relationships needs to lead to amazement and discomfort in the academic community, the population studied, in the city where it is inserted and in the society as a whole.

Thus, it is essential that the health team, particularly the nurse understand the phenomenon of gender-based violence and its impact on women's, family's and community's health so that their performance may be more focused on facilitating access to social support networks and strengthening of health promotion actions in the various levels of complexity of the Unified Health System.

Regarding the limitations of the study, we point out the non-inclusion of women representing other social classes and locations in the Federal District. Moreover, the analysis of gender relational approach was not possible for not including in the sample males individuals.

It is suggested that new researches be carried out in such a way that allows the participation of both partners which would permit full analysis of the ecology of genderbased violence.

Moura LBA ,Reis PED ,Faustino AM ,Guilhem D,Bampi LNS ,Martins G. VIVÊNCIAS DE VIOLÊNCIA EXPERIMENTADAS POR MULHERES DO DISTRITO FEDERAL: ESTUDO DESCRITIVO. Online braz. J. nurs. (Online); 10(3) set-dez. 2011. 


\section{REFERENCES}

1. Foucault M. Vigiar e punir: história da violência nas prisões. $37^{a}$ edição. Petrópolis: Vozes; 2010.

2. World Health Organization (WHO). WHO multi-country study on women's health and domestic violence against women. Geneva: WHO; 2005.

3. Ministério da Saúde. VIVA: Vigilância de violências e acidentes. Brasília: Ministério da Saúde; 2010.

4. Guedes RN ; Silva ATMC; Coelho EAC; Silva CC; Freitas WMF. The Marital Violence under a gender view: domination and possibility of destruction of the hegemonily idealized model of marriage. Online Brazilian Journal of Nursing [online]. 2007; [Access: 2011 May 20] ; 6(3). Available from:

http://www.objnursing.uff.br//index.php/nursing/article/view/j.16764285.2007.1103/261.

5. Barrett B J, St. Pierre M. Variations in women's help seeking in response to intimate partner violence: findings from a Canadian population-based study. Violence against women $2011 ; 17$ (1): 47-70.

6. Ali T S, Asad N, Mogren I, Krantz G. Intimate partner violence in urban Pakistan: prevalence, frequency, and risk factors. International journal of women's health 2011; 3 (1): 105-115.

7. Bronfenbrenner $\mathrm{U}$. Ecology of the family as a context for human development: research perspectives. Dev Psychol 1986; 22 (1): 723-42.

8. Gomes IS. Transmissão psíquica transgeracional e violência conjugal: um relato de caso. Bol Psicol 2005; 55 (123): 177-88.

9. Moura LBA, Moura B. Reflexões sobre conjugalidade violenta na condição moderna. In: Lima FR, Santos C, organizadores. Violência doméstica: vulnerabilidades e desafios na intervenção criminal e multidisciplinar. Rio de Janeiro: Lúmen Júris; 2009. p. 183-94.

10. Moura LBA, Moura BA. Um olhar sobre a questão das violências cometidas por parceiro íntimo contra mulheres. In: Moura LBA, editora. Empoderamento comunitário: uma proposta de enfrentamento de vulnerabilidades. Brasília: LetrasLivres; 2008. p. 107-28.

Contributions from authors: Conception and Design: Leides Barroso Azevedo Moura. Bibliographic Research: Leides Barroso Azevedo Moura, Andréa Mathes Faustino. Analysis, Interpretation and Writing of the Article: Leides Barroso Azevedo Moura, Andréa Mathes Faustino, Paula Elaine Diniz dos Reis, Luciana Neves da Silva Bampi, , Gisele Martins. Critical Review of the Article: Andréa Mathes Faustino, Dirce Guilhem, Paula Elaine Diniz dos Reis. Final Approval of the Article: Leides Barroso Azevedo Moura, Andréa Mathes Faustino, Dirce Guilhem Paula Elaine Diniz dos Reis.

Moura LBA ,Reis PED ,Faustino AM ,Guilhem D,Bampi LNS ,Martins G. VIVÊNCIAS DE VIOLÊNCIA EXPERIMENTADAS POR MULHERES DO DISTRITO FEDERAL: ESTUDO DESCRITIVO. Online braz. J. nurs. (Online); 10(3) set-dez. 2011. 